\title{
Implementation of Christian Religious Studies Curriculum for Students Character Formation in Public Senior Secondary Schools in Owerri Municipal, Imo State, Nigeria
}

\author{
Everlyn Oluoch-Suleh, Ph.D ${ }^{1 *}$, Osuji Gregory Ekene, Rev. Br. Ph.D ${ }^{2}$ \\ ${ }^{1}$ Marist International University College, P.O. Box 24450 Karen, 00502 Nairobi, Kenya \\ ${ }^{2}$ Godfrey Okoye University Ugwuomu-Nike, P.M.B. 01014, Thinkers' Corner, Enugu, Nigeria
}

DOI: $10.36348 /$ jaep.2020.v04i06.009 $\quad$ | Received: 05.06.2020 | Accepted: 12.06.2020 | Published: 16.06 .2020

*Corresponding author: Everlyn Oluoch-Suleh

\section{Abstract}

The study explored the challenges faced by the teachers of Christian Religious Studies (CRS) in the implementation of the senior secondary school curriculum for the character formation of public students in Owerri Municipal, Imo State, Nigeria. The study adopted a qualitative paradigm, specifically the collective case study design. Two research questions guided the study: What are the challenges inherent in the implementation of the CRS curriculum for the character formation of students? What are the possible solutions to these challenges? The study targeted students, teachers and principals from three public senior secondary schools. The sample size of the study was 66 . That is, 54 students, 9 teachers and 3 principals. The researchers employed maximum variation sampling technique in selecting the 3 schools for the study. They used homogeneous and purposeful random sampling techniques to select 54 students, automatic inclusion sampling technique to select 3 principals, and criterion sampling technique to select 9 teachers of CRS. The researchers used interview guide and focused group discussion guide for data collection. For data analysis, they transcribed the interviews, coded the data, categorised the data, derived themes from the categories, interrelated themes from each group of participants, and interpreted the meaning of themes. The findings of the study revealed that administration, teacher and student related factors were the main challenges. These pose threat to students' character formation. The study therefore recommended that teachers need to use discovery approaches, and use varied instructional resources in teaching. Furthermore, the school community needs to maintain a vibrant life of faith and integrity.

Keywords: Christian Religious Studies Curriculum, implementation, character formation, senior secondary school, Owerri Municipal.

Copyright @ 2020: This is an open-access article distributed under the terms of the Creative Commons Attribution license which permits unrestricted use, distribution, and reproduction in any medium for non-commercial use (NonCommercial, or CC-BY-NC) provided the original author and sources are credited.

\section{INTRODUCTION}

The current study is hinged on one of the objectives of the senior secondary school (SSS) Christian Religious Studies (CRS) curriculum. This objective is: "To help develop in the youth Christian attitudes and moral values" [1]. These Christian attitudes and moral values are humility, respect, love, kindness, justice, fair play, spirit of forgiveness, obedience, orderly behaviour or discipline, hard work and devotion to duty, and selfless service to God and humanity. Therefore, the CRS curriculum is a tool that helps the Nigerian youth to be disciplined and empowered for the good of the society.

In this study, character formation is the education that public senior secondary school (SSS) student in Owerri Municipal, Imo State, Nigeria acquires in the course of being exposed to the CRS curriculum. This enables him or her to be morally, socially, and transformation-oriented person. The CRS curriculum itself is a document of planned activities designed for this student to help him or her to have Christian attitudes, and develop virtues and moral values. Therefore, the implementation of this curriculum requires the use of varied instructional techniques and resources in order to help this student imbibe right attitudes to God and life, and right conducts to self and to others.

Character formation of students is a concern to stakeholders in education. This is because there has been a social outcry on the incidences of indiscipline in secondary schools. At the global level, Junger-Tas et al., [2] studied many faces of youth crime. Their study adopted a quantitative paradigm and focused on the 
behaviour of young people in 30 countries in Europe and America. The study revealed drug dealing, theft, vandalism, assault and indiscriminate shooting of staff and students, as the prevalent deviant acts of students. At the regional level, Nyabwari, Katola and Muindi [3] explored holistic Christian Education for the character formation of students in Nyamira County, Kenya. The study found that inadequate implementation of the school philosophy led to drug and substance abuse, sexual abuse, violence, and drunkenness among students. At the national level, Asiyai [4] surveyed students' indiscipline in three States in Nigeria. The study revealed that assault on teachers and prefects, vandalism, examination malpractice, substance abuse, and alcoholism were the most types of indiscipline cases among students.

The studies explored at the global, regional and national levels have identified the need for teachers to promote values in schools for the character formation of students. The social outcry about indiscipline in students may be attributed to the ways the teacher of CRS implements the curriculum. The implementation starts from the arrangement of the contents of the curriculum to its practical translation into action in the classroom. If for instance, the arrangement of the contents is not coherent and consistent, it may find it difficult to address the character formation of students. Furthermore, the way CRS is taught and the ethical behaviour of the CRS teacher enhance or negate the character formation of students [5].

At the global level again, in her content analysis, Brady [6] examined the values of teachers that inform classroom relationships. She focused on values education in secondary schools in Sydney, Australia. Her study revealed that the inability of the teacher to create warm and supportive classroom environments makes leaners to be involved in indiscipline cases. Similarly, Bogomilova [7] did a quantitative study in Eastern Europe. He focused on the problems of teaching Religion: Christianity, Islam, Judaism, and Buddhism in public schools in Bulgaria. The study found that lack of sufficiently well-trained Religion teachers, poor teaching skills of the teachers, and lack of resource materials for the subject were the pronounced problems in the teaching of Religion. Therefore, this led to increase in youth crime.

At the regional level also, the findings from the global level had some similarities. These were in the teaching skills of Religion teachers and the resource materials in the teaching and learning process. In their study, Wambui and Amukowa [8] adopted quantitative approach and elicited information from teachers and students. The study focused on constraints teachers are faced with in using life approaches to teach CRE in secondary schools in Nairobi East District, Kenya. The study found that teachers had inadequate resources, and they often used the lecture method in teaching due to wide syllabus. In the same vein, Situma [9] studied methods used by teachers to teach Christian Religious Education in secondary schools in Kimilili, Bungoma County, Kenya. Her study adopted a quantitative paradigm and specifically used survey research design. The study revealed that Christian Religious Education (CRE) teachers use lecture methods in teaching instead of the more collaborative learning methods such as group discussion, demonstration, class presentation, drama, discovery methods and audio-visual. The lecture method revealed in these studies is ineffective in helping learners to understand and retain content. Hence, CRE finds it difficult to achieve its intended objectives of imparting moral values in students.

More so, at the national level, the increase in the incidences of indiscipline in schools is assumed to be due to lack of role models from the school. Furthermore, it is assumed to be as a result of the nonpractical aspect of the implementation of the CRS curriculum. This is not far from the findings of Okosun [10] that among the causes of indiscipline in Nigerian secondary schools were poor teaching by some teachers, teachers' lateness and absenteeism, nonconducive school environment, and poor leadership of some school administrators. These findings agreed with Ememe, Ezeh, and Onwuchekwa [11], who found that teachers' method of teaching was one of the factors responsible for the acts of students' truancy in secondary schools in Abia State, Nigeria.

Similarly, Ogwu and Ezema [12] studied the influence of teaching methods on students' interest in Christian Religious Studies. They delimited the study to senior secondary school students in Igbo-Eze South Local Government Area of Enugu State, Nigeria and employed descriptive survey in their design. The study found that the teachers of CRS use poor, boring and obsolete methods such as memorization of Bible passages, dictation of notes and recitation, in teaching. According to the study, these obsolete methods make students to lose interest in the subject; hence increase in moral decadence.

The researchers in the current study are of the opinion that CRS is very important to the character formation of students. Therefore, the more the teachers of CRS use innovative methods in the teaching and learning of CRS, and exemplify themselves as role models to their learners, the more the students will develop interest in the subject. As a result, students' character formation is enhanced. For this purpose, the current study explored the challenges faced by the teachers of Christian Religious Studies (CRS) in the implementation of the senior secondary school curriculum for the character formation of public students in Owerri Municipal, Imo State, Nigeria. 


\section{Statement of the Problem}

Christian Religious Studies (CRS) occupies a positive and key position in secondary schools in Nigeria. Despite that, there has been increase in moral decadence leading to incidences of indiscipline cases in schools such as theft, examination malpractice, disobedience, disrespect, substance abuse, bullying, cultism, laziness, and sexual misconduct. These incidences of indiscipline disrupt school activities; as a result, put into test the efforts of the teacher of CRS, and pose threat to school effectiveness.

Some studies have revealed that most of the acts of indiscipline inherent in schools were as a result of poor teaching techniques of the teachers of CRS and lack of concrete instructional resources. Other causes of indiscipline cases in schools were as a result of lack of role models in schools and students' lack of interest in CRS. Therefore, the teachers of CRS need to implement the curriculum effectively in order to enhance the character formation of students.

Many scholars who researched on this phenomenon adopted quantitative and mixed methods research paradigms. Only a few research according to the literature reviewed used qualitative paradigm; however, the focus was on other Countries and States. Since the dependent variable of the current study was character formation, that is, the behaviour of students, pure qualitative paradigm was the best approach in developing an in-depth analysis of the phenomenon under study. It was against this backdrop, that this study used qualitative paradigm and explored the challenges faced by the teachers of Christian Religious Studies (CRS) in the implementation of the senior secondary school curriculum for the character formation of public students in Owerri Municipal, Imo State, Nigeria.

\section{Research Questions}

The following questions guided the study:

i. What are the challenges inherent in the implementation of the CRS curriculum for the character formation of students in Owerri Municipal, Imo State Nigeria?

ii. What are the possible solutions to the challenges in the implementation of the CRS curriculum for the character formation of students in Owerri Municipal, Imo State Nigeria?

\section{Significance of the Study}

This study is significant to the Ministry of Education, the Nigerian Educational Research and Development Council (NERDC), secondary schools, school administration, teachers of CRS, teachers in charge of discipline, teachers in charge of guidance and counselling, students, parents, the church, non-state actors and other researchers. This study is beneficial to these stakeholders in the following ways:
The Ministry of Education will directly benefit from this study. The findings will help the Ministry of Education to have well formulated policies on training and employment of qualified teachers of CRS with positive values to schools. Thy study will also be beneficial to the Nigerian Educational Research and Development Council (NERDC). The findings of the study will advise NERDC on the need to review the existing CRS curriculum and bring in some topics and instructional methodologies and resources that will help build the affective domain of the students.

To the secondary schools in Owerri Municipal, Imo State Nigeria; that is staff and students, the study will be beneficial to them in the following ways: Through this study, the school administration will see the need to give full administrative support to the teachers of CRS. This support is in the areas of instructional materials and in-service training. The support will help the teachers to be fully equipped for the character formation of students. For the teachers of CRS, the study also hopes to expose more innovative and practical pedagogical approaches to CRS. These practical teaching methodologies will help the teacher of CRS to influence the behaviour of the students positively.

The study will reduce the workload of teachers in charge of discipline. Through the study, the teachers in charge of discipline will be more at home with the students and be more focused on the productive nature of the school than looking for undisciplined students. For the teachers in charge of guidance and counselling, the study will help them achieve their objectives. One of their objectives is the positive pursuit of students. Therefore, when students become more focused on their school activities due to the positive influence of CRS on their behaviour, it helps to boost the morale of the counsellors.

Students will benefit in a special way in this study. The findings will enable students to see the need to embrace virtues such as honesty, hard work, obedience, cooperation, and responsibility. The study will also help them to shun vices such as theft, examination malpractice, disobedience, disrespect, substance abuse, bullying, laziness, cultism, and sexual misconduct. The study is also significant to parents, guardians and or sponsors of the students. They will benefit from the positive behavioural pursuits of their children and or wards. Their children and wards will learn how to be consistent in doing home chores, respect their elders, keep good friends and companies, take care of the home, and engage in more productive activities in the society.

The church will benefit in a special way in this study. This is because when the characters of the students are enhanced, they become more responsible citizens. This leads other young people to emulate their 
disciplined characters. By so doing, increase in virtuous life and decrease in vices. The other non-state actors such as the civil society and non-governmental organisations will also benefit immensely from this study. This is due to the fact that when students' characters are well formed through the CRS curriculum, they thrive for discipline and excellence in school, and the wider society.

Lastly, the findings of this study will add new knowledge in the academic field. The study will be relevant to other researchers who are interested in character formation of students. It will bring to their awareness the importance of the CRS curriculum in the character formation of students. In so doing, contributes to existing knowledge, theory, practice, and scholarship.

\section{Scope and Delimitations of the Study}

The content scope of this study is the challenges inherent in the implementation of Christian Religious Studies (CRS) curriculum. Their solutions are also part of the content scope. The study is delimited to three public senior secondary schools: two single sex schools; a boys' school and a girls' school, and a coeducation school in Owerri municipal. The level scope then is students of CRS, their teachers and the principals in senior secondary schools in Owerri Municipal. The justification for the choice of the schools was to get in-depth similarities and differences with regard to the phenomenon under study. As well, for the proposed site for the study; Owerri Municipal, and the senior students, it is assumed that the process of modernisation in the urban areas has brought in its wake myriad of problems. This makes students deviate from the standard norms of the society.

\section{Theoretical Framework of the Study}

This study was anchored on the Social Learning Theory developed by Bandura, Ross \& Ross [13]. The justification for the use of this theory was that it enabled the researchers to explore how the character of the student is formed as a result of the commitment of the teacher of CRS in teaching, the exemplary life that he or she leads. More so, the support the school administration gives to him or her.

According to the theory, there are four conditions necessary for social learning to take place. These are attention, retention, production, and motivation. These conditions helped the study to be more focused. This study found the theory relevant because recent researchers such as Atilano [14], Korir and Kipkemboi [15], and Akintayo and Adebola [16] who worked on similar phenomenon of the study used the theory as a hinge to their studies on the theory.

\section{Albert Bandura's Social Learning Theory}

The Social Learning Theory demonstrates that children's future behaviours are strongly influenced by observing the behaviour of adults and how these behaviours are rewarded and punished for their behaviours. In their lives, children observe a variety of people that can influence how they grow, develop, and behave. The behaviour of these people can define the child, and these influences include parents, siblings, friends, and teachers $[17,18]$. The people that children observe are referred to as models and their behaviours influence children. This is because, when children observe models, they encode some of their behaviours, remembering what they have seen and replicating such behaviours [19].

\section{Key Principles of Albert Bandura's Social Learning Theory}

Drawing from the Social Learning Theory, there are four conditions necessary for social learning to take place. They include: attention, retention, production and motivation. In the principle of attention, observers cannot learn unless they pay attention to what is happening around them. In retention, observers must not only recognise the observed behaviour, but also remember it at some later time.

Furthermore, in the condition of production, observers must be physically and or intellectually capable of producing the act. In many cases the observer possesses the necessary responses. In the principle of motivation, an observer will only act if there are some motivations behind the action. Therefore, the presence of reinforcement or punishment, either to the model or directly to the observer becomes most important here.

\section{Strengths of Albert Bandura's Social Learning Theory}

One of the key strengths of the Social Learning Theory is the fact that the researchers verified that children copy aggression. This was confirmed in their case study of 1961 [19, 20]. These scholars reiterated that the other strength of the Social Learning Theory is that many acts of aggression or tragedies were linked to violent and gruesome television shows. Additionally, that the experiment was rigorous enough to establish cause and effect relationship; that is, watching violent TV shows and acting them out.

The researchers in the current study believe that the theory easily handles inconsistencies in the child's behaviour. For instance, a child may be reinforced at school for good behaviour and punished at home due to bad behaviour. Similarly, this behaviour is optimistic for it suggests that given the right environment, any behaviour can be changed. According to Weebly [21], the theory gives an accurate picture of the way behaviours are learned. The researcher in the current study is of the view that this theory offers a way to integrate social and cognitive theories. This actually allows and accounts for cognitive processes and 
explains a large number of behaviours. The theory is actually easy to understand when applied in a study.

\section{Weaknesses of Albert Bandura's Social Learning Theory}

The researchers in the current study are of the opinion that there was biasness in the Social Learning Theory. The reason for this is that the participants of the study came from one case; the Stanford University Nursery, and the sample size was small for the general conclusion of children's behaviour in the Bobo doll experiment.

Some of the weaknesses of the theory that some researchers identified were: the theory could not explain why some children watch these violent television shows and play these games yet they never copy them $[19,20]$. In addition, that there are some children who are naturally aggressive even if they play violent games or watch gruesome television shows. Another important weakness the researcher of the current study identified was that the theory did not take into account what one person views as punishment; another person may view it as reward. This is very true because in the present society, especially in schools, some students may be happy cutting grass in the field as their punishment because they may not like to be in class for lessons. Therefore, any teacher who wants to punish them because they did not carry out their class assignment for example, and sends them out to cut grass in the field, instead of being a punishment for them, it turns to be reward for them. This is where the researchers should have reviewed their conclusions about punishment and reward.

\section{Application of Albert Bandura's Social Learning Theory to the Study}

The theory emphasised on the affective domain of learning. Attention and retention account for acquisition or learning of a model's behaviour while production and motivation control the performance. With this, in the classroom, all teachers are supposed to be role models and it is their responsibility to ensure that they behave in a way that meets the expectations of a role model [17]. In doing so, they can help develop and shape students in a way that is beneficial to their character formation.

In the classroom, there is a need for students to get a chance to observe and model the behaviour that leads to positive reinforcement. Therefore, the CRS teacher needs to encourage collaborative learning. The teacher also needs to provide incentive and the supportive environment for the behaviour to happen $[19,18]$. The CRS teacher needs to teach CRS using discussion, forums, debates, and stories as part of his or her instructional techniques. In the same vein, he or she needs to employ resource materials in class that can have positive impact on his or her students. This is because these techniques and resources will retain the attention span of the students, motivate them and enable them to put into practice what they learnt [22].

\section{METHODOLOGY}

The researchers adopted a qualitative paradigm in the study and used case study research design. Case study helped the researchers carry out an in-depth analysis of the phenomenon under study. The researchers specifically made use of collective case study in order to explore differences and similarities on the phenomenon under study.

The study was carried out in Owerri Municipal, Imo State, south-eastern part of Nigeria. Owerri Municipal is the seat of power for Imo State Government. It has many private and public institutions of learning: nursery schools, primary schools, and institutions of higher learning. All these have a lot of influence to the urban life of this city where the schools for this study are located.

The study targeted students, teachers and principals from the senior class of nine public secondary schools in Owerri Municipal. The justification for choosing these schools in Owerri Municipal were: they teach CRS, they are located in very populated areas of the town with varied economic, religious, social, political and educational activities. In addition, there is an assumption that senior students are mostly involved in incidences of indiscipline in the school

The researchers used three public senior secondary schools out of the nine public secondary schools in Owerri Municipal [23]. Since it was a qualitative study, it was necessary to use a small sample in order to have an in-depth study of the phenomenon [24]. The researchers used maximum variation sampling technique in selecting the three schools for the study. The purpose of using this sampling technique to select the schools was to discover and or uncover central themes, core elements, and or shared dimensions that cut across the cases, and to get diverse variations with regard to the phenomenon under study. For the students, the researchers used homogeneous and purposeful random sampling techniques to select 54 of them. The reason for these homogeneous and random sampling was to randomly bring together people of similar backgrounds and experiences. The sampling techniques facilitated focus group discussion, and helped get robust data for the study. The researchers employed criterion sampling technique to select 9 teachers of CRS. These teachers teach the senior classes and they were also selected because of their interest in the study. The researchers also use automatic inclusion technique to select the 3 principals for the study. These principals came from the senior secondary school administration. 
The researchers used focused group discussion guide to collect data from students, and interview guides for teachers and principals. They ascertained the trustworthiness of the instruments. They sought the assistance of specialists in measurement and evaluation, and curriculum studies. These specialists made constructive comments about items on the instruments and the researchers effected the changes. Later, the researchers subjected the instruments for pilot testing to participants similar to the sampled group. The researchers had constant debriefing and peer scrutiny with their fellow researchers about the findings from the pilot testing. Later, the researchers went in for data collection of the study. The researchers collected data through focus group discussion and face-to- face interviews. The focus group discussion was with students, and the face-to-face interviews were with the teachers and the principals.

For data analysis, the researchers transcribed the interviews, manually coded the data, categorised the data, derived themes from the categories, interrelated themes, interpreted the meaning of themes and validated the accuracy of the information. The researchers also ensured that they adhered to ethical rules governing and guiding academic research study. This is because research is governed by rules and regulations which help to reduce conflicts and misunderstandings among researchers and participants.

\section{FINDINGS}

Challenges Inherent in the Implementation of the Christian Religious Studies Curriculum for the Character Formation of Students

Participants of the study identified some challenges in the implementation of the Christian Religious Studies (CRS) for the character formation of students. Many themes emerged from the responses of the participants. The researchers interrelated the themes and came up with major themes. Figure-1 illustrates the major themes that emerged across the Cases as the challenges inherent in the implementation of CRS curriculum for students' character formation in public senior secondary schools in Owerri Municipal, Imo State, Nigeria.

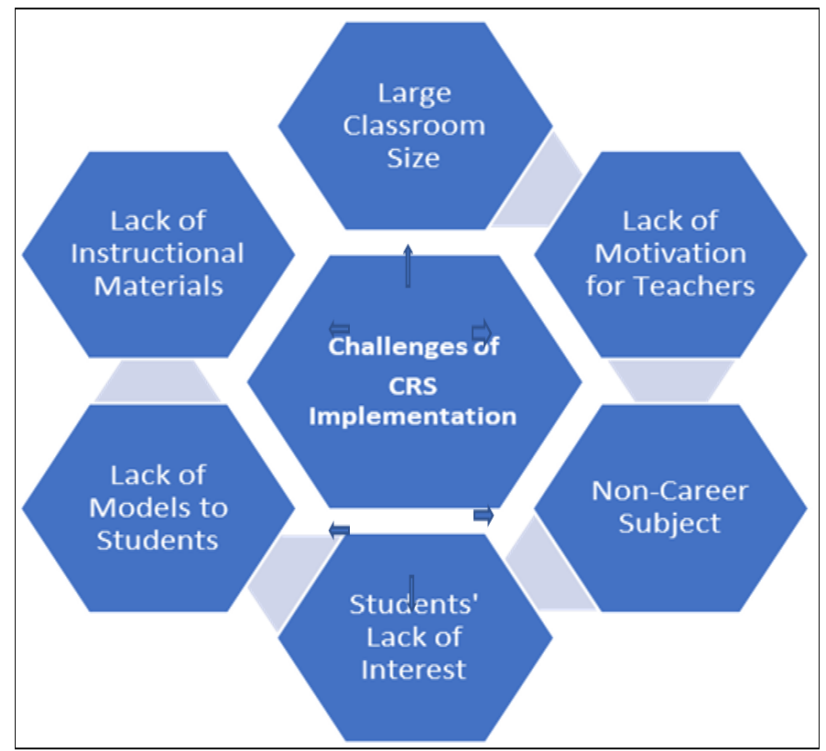

Fig-1: Challenges in the Implementation of Christian Religious Studies Curriculum for the Character Formation of Students

Possible Solutions to the challenges in the implementation of the Christian Religious Studies Curriculum for the Character Formation of Students

Figure-2 shows the themes that emerged from the different participants across the Cases as the possible solutions to the challenges in the implementation of the CRS curriculum for the character formation of senior students in public secondary schools in Owerri Municipal, Imo State, Nigeria. 


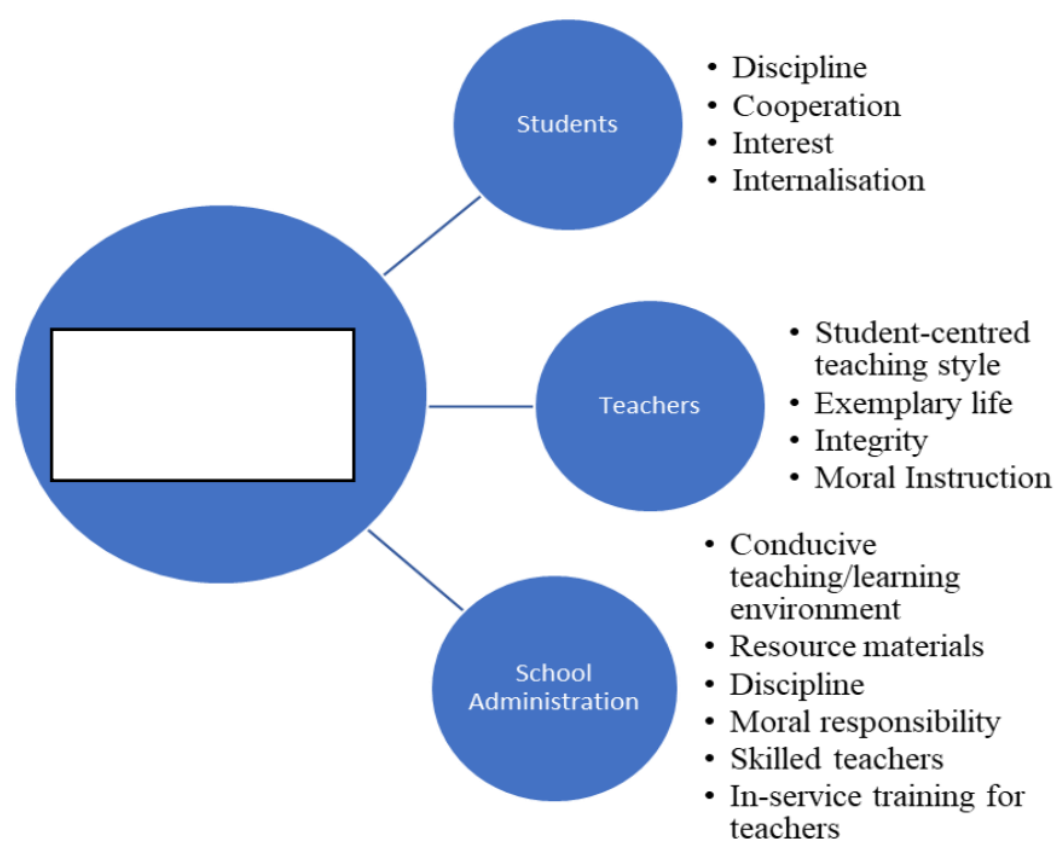

Fig-2: Possible Solutions to the Challenges in the Implementation of the Christian Religious Studies Curriculum for the Character Formation of Students

\section{DISCUSSION OF THE FINDINGS}

Figure-1 portrays the major themes that emerged from the study as the challenges inherent in the implementation of the Christian Religious Studies Curriculum for the character formation of students in public senior secondary schools in Owerri Municipal of Imo State, Nigeria. The study revealed that for the enhancement of the character of students, CRS needs to be taught in a more committed manner by the CRS teacher. Furthermore, that students need to show interest in the subject. On the issue of interest, a student participant expressed:

Some of the students do not show interest in CRS because there is no career prospect in the subject. More so, our CRS teacher is getting old and she cannot control most students who disturb in class. Also, she finds it difficult to motivate students in class. (Student 9, Case A, FGD, November 14, 2019)

In relation to students' lack of interest as a challenge to the implementation of the CRS curriculum for the character formation of public senior secondary school students in Owerri Municipal, Imo State, Nigeria, a principal participant affirmed:

It is difficult to elicit students' interest because they do not see a relationship between the subject itself or the values taught and success in their future careers. Besides, many CRS teachers lack the requisite motivation as the society and government seem to promote science subjects. Also, there is general lack of teachers who walk their talk when it comes to moral issues. Even the school hardly lives by its moral teachings. (Principal C, Interview, November 28, 2019)

The findings are in harmony with Ogwu and Ezema [12] that most senior secondary students in Nigeria have no interest in learning CRS due to the fact that it is not well taught, its content is narrow and there is no career prospect in it. The findings also confirm Anwar [25] that the society, especially Al-Kautsar Lampung lays more emphasis on Science subjects than Religious studies that enhances character formation of students.

In order to elicit students' interest in CRS; the teachers of CRS need to be fully motivated. This is because they are the key factors that implement the curriculum for the character formation of students. Lack of motivation in the areas of remuneration and instructional materials has made some of them not be creative in their teaching methodology. On the need for instructional materials, a participant emphasised:

It is not only reading the Bible; looking for textbooks I will need to prepare for some topics is a big challenge. Furthermore, the class is overcrowded due to lack of class space and inadequate tables and chairs. This makes students uncomfortable in class. (CRS Teacher B, Interview, November 21, 2019)

In addition, looking for these instructional materials requires needing more time to fully utilise them in the classroom. The study found that time is a challenge in the effective implementation of the CRS curriculum for the character formation of students. A participant also stated that: "CRS requires a lot of illustrations, stories and explanations to enable the 
students understand what the teacher is teaching. Therefore, it needs to be allocated more time in the timetable" (CRS Teacher A, Interview, December 5, 2019). This assertion is an indication that there is need for more commitment in the teaching of CRS in order to enhance the character formation of students.

These findings are consistent with the study of Anggraini and Kusniarti [26] that inadequate resource materials affect the implementation of character education. It also agrees with Obaga [27], that students' negative attitude towards CRS, lack of motivation of teachers, and inadequate time impede effective implementation of CRS. Furthermore, it confirms Jebungei [28], that lack of role models and moral degradation in the society affect commitment in the implementation of CRS curriculum for the character formation of students. The findings also are in agreement with the Social Learning Theory developed by Bandura, Ross \& Ross [13] that this current study is anchored on.

Figure-2 depicts possible solutions to the challenges in the implementation of the CRS curriculum for the character formation of public senior secondary school students in Owerri Municipal, Imo State, Nigeria. The study concretely directs the solutions to the challenges to students, teachers and the administration. For the students, the study revealed that there was need for them to be disciplined at all times, cooperate with the school for their good, and have interest in CRS. With regard to interest, Ogwu and Ezema [12] reveal that it acts as a very powerful motive to individual's behaviour that energetically determines choices made. Students were also required to internalise the values they receive from school through CRS, Thursday moral instructions, their school clubs, and the positive lifestyle of their teachers and peers. A student participant emphasised:

We need to show more interest in the things of God, read the Bible and go to Church regularly; doing and practising the Word of God and not only hearing it deceiving ourselves. Teachers also should try as much as possible to teach students how to live their lives as Christians in order to make heaven in the end. (Student 8, Case B, FGD, November 18, 2019)

From the study, there was the general feeling to make CRS compulsory in schools in order to retain the interest of students in it. This concurs with the studies of Itolondo [29], Igwe, Rufai, and Olufemi [30], Jebungei [28], and Wambui and Amukowa [8], that when you make the subject compulsory, students will attach more importance to it. However, Obaga [27] disagrees with this assertion. Her study in Kenya revealed that Christian Religious Education should be optional due to its lack of future prospect.
For teachers in general, the study demanded from them the use of discovery or heuristic approaches in teaching whereby they cater for the needs of the students. On the issue of appropriate methods in teaching, the finding is consistent with $\mathrm{Njoku}$ and Njoku [31] who established that learner-centred teaching approaches help greatly in attaining the learning outcomes.

The study further revealed that teachers needed to live exemplary lives; a life of integrity within and outside the school, and to take seriously the inculcation of values to students through moral instructions. This would help to form the character of students and make them behave well all the time in and outside the school. One of the teacher participants expressed:

The CRS teacher should be a role model whereby every student and other teachers should emulate. $\mathrm{He}$ or she should be practising whatever he or she teaches. He or she should be a typical example of do as I do. This will help transfer values in the students. (CRS Teacher C, Interview, December 6, 2019)

The finding agrees with Brady [6], and Thornberg and Oğuz [32] who revealed that the teacher's ethical life creates awareness in the learners and spurs them on to follow suit. It is also consistent with the Social Learning Theory that this study is anchored on that demonstrates that children's future behaviours are strongly influenced by observing the behaviour of adults and how these behaviours are rewarded and punished for their behaviours.

For the school administration, the study found that there was need for them to create an environment conducive to teaching and learning. Also, to always provide resource materials for the CRS teachers, support the CRS teachers in instilling discipline in students, and to maintain always the session of Thursday moral instruction. More so, to vouch for the employment of qualified CRS teachers, and always avail the CRS teachers for in-service training so as to help the students build their character positively. One of the principal participants reiterated: "The school should provide the right environment for the teaching and learning of CRS. It should train and retrain CRS teachers to incorporate values analysis in their teaching" (Principal B, Interview, November 28, 2019).

The implication of the quote is that there is need for the school administration to fully support the work of the CRS teacher for the character formation of the students. The CRS teacher needs to be given instructional materials, she or he needs to have the opportunity to go for in-service training for the good of the school; also, the school needs to help him her in disciplining errant students. This concurs with the 
studies of Itolondo [29], Jebungei [28], and Wambui and Amukowa [8] that administrative support of the CRS teacher in the areas of instructional materials, incentives, and in-service training enables him or her to be committed in his or her duties.

\section{CONCLUSIONS AND RECOMMENDATIONS CONCLUSIONS}

The Christian Religious Studies (CRS) curriculum was designed to teach students about God, moral and societal values. As a subject, CRS helps in the character formation of students, and for a sustainable acquisition of knowledge, skills, values and attitudes for the transformation of the Nigerian society. In spite of that, the implementation of the senior secondary school Christian Religious Studies curriculum for the character formation of students in public schools in Owerri Municipal, Imo State, Nigeria has not yet met its aim.

Therefore, from the findings, the study concludes that: Large classroom size, lack of instructional resources, lack of motivation for teachers, lack of models to students, students' lack of interest in CRS, and CRS seen as a non-career subject were some of the challenges teachers of CRS are faced with in implementing the CRS curriculum for the character formation of students. Hence, there was need for the students to internalise the values they learn in class. Teachers were to use student-centred approaches in teaching. More, so, the school administration was to create an environment conducive to teaching and learning.

\section{RECOMMENDATIONS}

The study had explored the challenges faced by the teachers of Christian Religious Studies (CRS) in the implementation of the senior secondary school curriculum for the character formation of public students in Owerri Municipal, Imo State, Nigeria. Based on the findings of the study therefore, the researchers make the following recommendations to the different stakeholders as follows:

\section{Ministry of Education}

The Ministry of Education has the responsibility to employ teachers to public schools in Imo State. Since the study found that some teachers are not role models to students due to their lifestyle, the Ministry should ensure that it employs teachers with Christian values, who are also role models in order to positively influence the character of students.

\section{Secondary Education Management Board (SEMB)}

The Secondary Education Management Board (SEMB) oversees the affairs of the schools in Owerri zone, and Owerri Municipal is part of its mandate. From the findings of the study, lack of instructional resources was one of the challenges the teacher of Christian Religious Studies (CRS) is faced with in the implementation of CRS curriculum for students' character formation. Therefore, SEMB should liaise with the Imo State Ministry of Education and provide varied instructional materials to schools for effective teaching and learning of CRS. These instructional resources should be supplied to the schools at the beginning of every term for effective teaching and learning. SEMB should on monthly basis supervise the work of the CRS teachers in order to ensure proper implementation of the CRS curriculum for the character formation of students.

\section{Principals}

Since good behaviour thrives in a serene environment, the school administration should provide the right environment for the teaching and learning of CRS: First, principals need to reduce the class size; 1:30 is preferable for optimal delivery of the CRS. This is because large class sizes interfere in the inculcation of values in each learner. Individualized learning thrives most in a manageable classroom where all teaching and learning facilities are available. Second, the principal needs to send termly report to SEMB on the progress and challenges of the school. The principal is to ensure that SEMB provides relevant and adequate instructional resources for the teaching and learning of CRS. Third, the principal is mandated to recommend to the Ministry of Education through SEMB, in-service training and professional development for the teachers of CRS so as to equip them fully for the task of character formation of students. This should be done every term.

\section{Teachers}

Teachers are the key agents of curriculum implementation. The study found that teachers mostly use the teacher-centred approaches in teaching instead of the learner-centred approaches. This hinders the transfer of values in the learners. Therefore, at every lesson, teachers should use learner-centred approaches such as drama, role play, debate, discussion, and demonstration, in teaching. Furthermore, they have to use varied instructional resources such as video clips, charts, maps, PowerPoint, and realia in teaching. These will help to sustain the interest of the students, help them to understand what they have been taught, and help transform their lives positively. Also, the teachers should on daily basis endeavour to live a life of integrity and always maintain discipline among students without any fear or favour.

\section{Students}

The CRS curriculum is designed for students. Therefore, they are the chief consumers of the curriculum. However, the study found that students lack interest. As a result of this, they are mostly involved in indiscipline cases. The study therefore recommends that students should develop interest in CRS. At every CRS lesson, they should endeavour to bring their textbooks, Bibles, and writing materials so as to read texts, discuss 
and apply them in their daily lives. They have to always come to class and participate fully during CRS lessons. They should also take as a duty to always live exemplary life in and outside the school.

\section{REFERENCES}

1. Nigerian Educational Research and Development Council (NERDC). (2012). Senior secondary school curriculum: Christian Religious Studies for SS 1-3. Abuja: NERDC.

2. Junger-Tas, J., Marshall, I. H., Enzmann, D., Killias, M., Steketee, M., \& Gruszczynska, B. (2012). The many faces of youth crime: Contrasting theoretical perspectives on juvenile delinquency across countries. London: Springer.

3. Nyabwari, B. C., Katola, M. T., \& Muindi, D. (2013). Holistic Christian Education for character formation in Seventh-Day Adventist Church sponsored secondary schools in Nyamira County, Kenya. International Journal of Academic Research in Progressive Education and Development, 2(1):244-257.

4. Asiyai, R. I. (2013). Indiscipline in Nigerian secondary schools: Types, causes and possible solution. African Journal of Education and Technology, 2(1), 39-47.

5. Osuji, G. E. (2017). Influence of Christian Religious Studies implementation on students' character formation in public senior secondary schools in Owerri Municipal, Imo State, Nigeria (Unpublished doctoral dissertation). Nairobi: The Catholic University of Eastern Africa.

6. Brady, L. (2011). Teacher values and relationship: Factors in values education. Australian Journal of Teacher Education, 36 (2), 56-66.

7. Bogomilova, N. (2015). Problems of teaching religion in public schools in Bulgaria toady: Retrospective and prospective. Occasional Papers on Religion in Eastern Europe, 35(1), 10-25.

8. Wambui, N. A., \& Amukowa, W. (2013). Constraints facing teachers of Christian Religious Education in using life approach in secondary schools in Nairobi East District in Kenya. Academic Journal of Interdisciplinary Studies, 2(2), 353-364.

9. Situma, J. (2016). Methods used by teachers to teach Christian Religious Education in secondary schools in Kimilili in Bungoma County, Kenya. British Journal of Education, 4(1), 18.

10. Okosun, J. (2010). Sports as instrument for controlling deviant acts among students of secondary schools in Nigeria. Europan Journal of Educational Studies, 2(1):7-12.

11. Ememe, O. N., Ezeh, C. C., \& Onwuchekwa, G. U. (2013). Truancy and academic performances of students in secondary schools in Aba North, Abia State South-East Nigeria. International Journal of Research Development, 2(1):1-9.

12. Ogwu, E. N., \& Ezema, A. A. (2016). Influence of teaching methods on students' interest in Christian
Religious Studies curriculum. International Journal for Research in Social Science and Humanities Research, 1(6):1-8.

13. Bandura, A., Ross, D., \& Ross, S. A. (1961). Transmission of aggression through the imitation of aggressive models. Journal of Abnormal and Social Psychology, 63(1):575-582.

14. Atilano, E. D. (2014). Pedagogy and cultural manifestations in the weaving practices of the Yakan tribe. Open Journal of Social Sciences, 2, 65-70.

15. Korir, D. K., \& Kipkemboi, F. (2014). The impact of school environment and peer influences on students' academic performance in Vihiga County, Kenya. International Journal of Humanities and Social Science, 4(5):240-251.

16. Akintayo, J. B., \& Adebola, A. (2015). Western entertainment television programmes: A catalyst for behavioural tendencies among students of Babcock and Covenant universities. New Media and Mass Communication, 42:56-68.

17. Nesbitt, C. (2013). Bandura, the theory of social learning and education. Retrieved from https://christophernesbitt.wordpress.com/2013/02/ 07/bandura-the-theory-of-social-learning-andeducation/

18. Johnson, A. P. (2014). Education psychology: Theories of learning and human development. Minnesota: National Science Press.

19. Brown, K. (2013). Strengths and limitations of the social learning theory. Retrieved from https://prezi.com/rdupzxlmax0b/strengths-of-thesocial-learning-theory

20. Vergara, J. (2013). Strengths and weaknesses of the social learning theory. Retrieved from http://www.scribd.com/doc/127945354/Strengthsand-Weaknesses-of-the-Social-LearningTheory\#scribd

21. Weebly, S. O. (2014). Social learning theory of Albert Bandura. Retrieved from http://bandurasociallearningtheory.weebly.com/str engths-weaknesses.html

22. Spencer, R. (2015). How to apply social learning theory for effective e-learning. Retrieved from https://www.trainingindustry.com/blog/blogentries/how-to-apply-social-learning-theory-foreffective-elearning.aspx

23. Secondary Education Management Board (SEMB). (2019). School statistics. Owerri: SEMB.

24. Creswell, J. W. (2013). Qualitative inquiry and research design: Choosing among five approaches ( $3^{\text {rd }}$ ed.). Thousand Oaks, CA: Sage.

25. Anwar, C. (2015). Learning value at senior high school Al-Kautsar Lampung for the formation of character. Journal of Education and Practice, 6(9):40-45.

26. Anggraini, P., \& Kusniarti, T. (2016). The implementation of Character Education model based on empowerment theatre for primary school 
students. Journal of Education and Practice, 7(1):26-29.

27. Obaga, A. M. (2009). The role of Christian Religious Education in character formation among the primary school youth, Nyansiongo Central Division in Borabu District, Kenya (Doctoral dissertation). The Catholic University of Eastern Africa, Nairobi, Kenya.

28. Jebungei, K. N. (2013). Overcoming the challenges facing secondary schools teachers in using Christian Religious Education to convey values to students in Eldoret Municipality, Kenya. International Journal of Humanities and Social Science, 3(15):271-278.

29. Itolondo, W. A. (2012). The role and status of Christian Religious Education in the school curriculum in Kenya. Journal of Emerging Trends in Educational Research and Policy Studies, 3(5):721-729.

30. Igwe, R. O., Rufai, S. R., \& Olufemi, A. G. (2013). Social reconstruction through Religious Education: A survey on Nigeria. Humanity \& Social Sciences Journal, 8(1):10-18.

31. Njoku, N. C., \& Njoku, D. I. (2015). Challenges to effective implementation of Christian Religious Studies curriculum: A study of secondary school pupils in Ebonyi State of Nigeria. Journal of Education and Practice, 6(18):176-180.

32. Thornberg, R., \& Oğuz, E. (2013). Teachers' views on values education: A qualitative study in Sweden and Turkey. International Journal of Educational Research, 59(1):49-56. 